\title{
Penetration of digoxin into cerebrospinal fluid
}

\author{
G. D. SCHOTT \\ M.D., M.R.C.P.
}

D. W. HolT*
Ph.D.

\author{
A. M. HAYleR* \\ B.Sc. \\ The National Hospitals for Nervous Diseases, Queen Square, London WC1 3BG, and \\ *The Poisons Unit, Guy's Hospital, London SEI 9RT
}

\begin{abstract}
Summary
The concentration of digoxin in the cerebrospinal fluid (CSF) of ten patients receiving conventional oral doses of this cardiac glycoside has been measured by a radioimmunoassay technique. Digoxin was undetected in eight patients and barely detectable in two, suggesting the presence of a significant blood-CSF barrier for digoxin. The implication of these findings is discussed.
\end{abstract}

\section{Introduction}

The importance of the cardiac glycosides in the treatment of a variety of heart diseases is firmly established and, although therapeutic problems remain, they are diminished by measurement of plasma levels of these drugs (Editorial, 1975). There has, however, been recent interest in the potential use of cardiac glycosides in neurological practice, including treatment of hydrocephalus (Neblett et al., 1972), benign intracranial hypertension (Schott and Holt, 1974) and mania (Naylor et al., 1975). Whilst CSF secretion by the choroid plexus may be influenced by these glycosides (Davson, 1967), effects resulting from the presence of digoxin in brain and CSF have also been proposed as a rationale for some of these therapeutic attempts, although the degree of penetration of these drugs remains controversial. The concentration of digoxin has therefore been investigated in the CSF of patients given this drug orally in doses resulting in plasma levels within the therapeutic range found useful in clinical cardiac practice.

\section{Methods}

The study included ten patients admitted to the National Hospitals for Nervous Diseases, London, whose routine management included examination of spinal CSF obtained by lumbar puncture or as part of a myelogram procedure. Details of the patients

Correspondence: Dr G. D. Schott, Department of Neurology, King's College Hospital, Denmark Hill, London SE5 9RS. are indicated in Table 1. Five patients (Group 1) were receiving long-term digoxin therapy $(0 \cdot 125$ $0.25 \mathrm{mg}$ daily) before admission to hospital; five others (Group 2), free from cardiac disease, gave informed consent and received 7-10 days oral digoxin, commencing with digoxin B.P. $0.25 \mathrm{mg}$ t.d.s. over $24 \mathrm{hr}$, followed by $\mathbf{0 . 2 5} \mathrm{mg}$ daily or twice daily up to the time of obtaining CSF. This project received prior approval from the Hospitals' Medical Ethics Committee.

CSF was obtained at least $8 \mathrm{hr}$ after the preceding dose of digoxin and, in addition to routine examination of the fluid, 1-2 $\mathrm{ml}$ were retained for digoxin assay and in five patients (case nos. 3-7) also for sodium, potassium and calcium concentration determinations. Simultaneous heparinized venous blood was also obtained and plasma digoxin, sodium, potassium, urea and calcium levels measured. An additional plasma digoxin sample was obtained $24 \mathrm{hr}$ before lumbar puncture in patients in Group 2, also at least $8 \mathrm{hr}$ after the previous dose of digoxin. Plasma digoxin was measured using a radioimmunoassay technique employing ${ }^{125}$ I-labelled digoxin (Holt and Benstead, 1975). For the measurement of digoxin in CSF the same procedure was adopted but the sample results were compared with digoxin standards prepared in normal CSF collected from patients not receiving digoxin. Standards were assayed in duplicate and samples in triplicate. The within-assay coefficients of variation at 0.6 and 2.5 $\mathrm{nmol} / 1(0.5$ and $2.0 \mathrm{ng} / \mathrm{ml})$ in the plasma assay were 8 and $5.5 \%$ respectively. The limit of sensitivity for the plasma assay was $0.13 \mathrm{nmol} / 1(0.1 \mathrm{ng} / \mathrm{ml})$ and, within each assay, standards covering the range $0-7 \cdot 7$ $\mathrm{nmol} / 1(0-6.0 \mathrm{ng} / \mathrm{ml})$ were determined. For the assay of digoxin in CSF standards covering the range 0-3.8 nmol/1 $(0-3.0 \mathrm{ng} / \mathrm{ml})$ were determined. Conventional methods for estimation of electrolytes, urea and CSF protein were employed.

\section{Results}

All ten patients at the time of obtaining CSF had 
TABle 1. Age, sex, condition and steady-state plasma digoxin concentration of patients studied

\begin{tabular}{|c|c|c|c|}
\hline Case no. & $\begin{array}{l}\text { Age } \\
\text { and sex }\end{array}$ & Condition & $\begin{array}{l}\text { Plasma digoxin } \\
\quad(\mathrm{nmol} / \mathrm{l})\end{array}$ \\
\hline \multicolumn{4}{|l|}{ Group 1} \\
\hline 1 & $57, \mathrm{~F}$ & $\begin{array}{l}\text { Atrial fibrillation, mitral } \\
\text { valve disease, occipital } \\
\text { infarcts }\end{array}$ & $1 \cdot 7$ \\
\hline 2 & 79, M & $\begin{array}{l}\text { Congestive cardiac failure, } \\
\text { motor neurone disease }\end{array}$ & $0 \cdot 8$ \\
\hline 3 & 63, M & $\begin{array}{l}\text { Atrial fibrillation, } \\
\text { hydrocephalus }\end{array}$ & 0.9 \\
\hline 4 & $67, F$ & $\begin{array}{l}\text { Congestive cardiac failure, } \\
\text { peripheral neuropathy }\end{array}$ & $1 \cdot 3$ \\
\hline 5 & $64, M$ & $\begin{array}{l}\text { Congestive cardiac failure, } \\
\text { tabes dorsalis }\end{array}$ & $2 \cdot 4$ \\
\hline \multicolumn{4}{|l|}{ Group 2} \\
\hline 6 & $31, F$ & Disseminated sclerosis & $1 \cdot 1$ \\
\hline 7 & $58, \mathrm{~F}$ & Disseminated sclerosis & $1 \cdot 5$ \\
\hline 8 & $37, \mathbf{M}$ & Benign intracranial pressure & 1.9 \\
\hline 9 & $42, \mathrm{M}$ & $\begin{array}{l}\text { Post-encephalitic manic } \\
\text { depressive }\end{array}$ & $1 \cdot 4$ \\
\hline 10 & $29, \mathrm{~F}$ & Suspected thoracic disc & 0.9 \\
\hline
\end{tabular}

plasma digoxin levels well within the range of sensitivity of the radioimmunoassay, and similar levels were found in the preliminary samples from the patients in Group 2. CSF digoxin was undetected in eight patients and in two (case nos. 5 and 8) was 0.26 $\mathrm{nmol} / 1(0.2 \mathrm{ng} / \mathrm{ml})$. Plasma electrolytes and urea remained normal throughout the study in all patients in Group 2 and in two patients in Group 1, three others having blood urea concentrations of 8.3$13.3 \mathrm{mmol} / 1(50-80 \mathrm{mg} / 100 \mathrm{ml})$. In the five patients in whom CSF calcium, potassium and sodium concentrations were measured, normal results were obtained.

CSF protein concentrations ranged from 260 to $1330 \mathrm{mg} / \mathrm{l}$. The latter value, noted in only one patient, was associated with a traumatic tap, 10,000 red blood cells $/ \mathrm{mm}^{3}$ being present; the CSF cell counts on other patients were less than 300 cells/ $\mathrm{mm}^{3}$. Features of digoxin toxicity were not encountered in any patient and in patients in Group 2, serial electrocardiograms remained normal and the clinical condition unchanged.

\section{Discussion}

There is increasing evidence that the nervous system plays a prominent part in the cardiac effects of the digitalis glycosides (Gillis, Pearle and Levitt, 1975), including a central, neurally mediated coronary vasoconstrictor effect (Garan, Smith and Powell, 1974). Both the pharmacological action of these glycosides on the nervous system and their neurological, psychiatric and possibly visual toxic effects that occur with higher dosage might be attributable to the presence of the drug in the brain.
Uptake of digoxin into the brain could occur by passage directly across a blood-brain barrier or indirectly via the CSF. The low concentration of digoxin in human brain tissue found post mortem (Doherty, Perkins and Flanigan, 1967) has suggested the presence of some form of blood-brain barrier, which may provide the central nervous system with protection from the potentially dangerous effects of the cardiac glycosides. The present findings imply the presence of at least a blood-CSF barrier for digoxin.

In the present study, digoxin was not detected in significant amounts in the CSF of patients receiving the drug in conventional dosage. Plasma digoxin concentrations in these patients were within the range associated with cardioactivity and were well above the limit of detection of the assay. This observation is at variance with the findings of Bertler, Andersson and Wettrell (1973), who, using a modified ${ }^{86} \mathrm{Rb}$ assay technique, found CSF digoxin in a concentration $25-33 \%$ of that present in plasma, although plasma levels were not stated; that the results were obtained from infants rather than adults, as in this report, may be relevant. The radioimmunoassay technique used in this study is sufficiently sensitive to detect digoxin in plasma above concentrations of $0.13 \mathrm{nmol} / 1(0.1 \mathrm{ng} / \mathrm{ml})$ and reliable measurements can be made above $0.26 \mathrm{nmol} / \mathrm{l}(0.2$ $\mathrm{ng} / \mathrm{ml}$ ). The sensitivity of the assay was similar in CSF and therefore the method could be expected to measure CSF digoxin concentrations of the magnitude reported by Bertler et al. (1973). The present authors cannot attribute the difference in their findings to delay in penetration of the glycoside 
since, even in patients in Group 2, maintenance therapy had been instituted for at least 1 week, and plasma digoxin levels one day before and at lumbar puncture were similar. The wide variety of underlying clinical conditions encountered in these patients makes it most unlikely that in any one was either a specific barrier to penetration or elimination process contributory.

Penetration of digoxin in CSF has been noted after intravenous administration of large doses of digoxin to dogs (Garan, Smith and Powell, 1974): using radioimmunoassay, digoxin was detected in CSF within 2 min of injection and there was a close temporal relationship between the concentration profile of digoxin in CSF and the magnitude of peripheral vascular resistance changes. After $50 \mathrm{~min}$ the plasma : CSF ratio was approximately $12: 1$, but later measurements were not reported and therefore the time course for the elimination of digoxin from CSF and whether this ratio was maintained over a prolonged period are not known. Six hours after intravenous administration of $1 \mathrm{mg}$ digoxin to a $20 \mathrm{~kg} \mathrm{dog}$, digoxin was undetected in CSF despite a plasma digoxin concentration of $13 \mathrm{nmol} / 1$ (10 $\mathrm{ng} / \mathrm{ml}$ ) (D.W.H., unpublished observation), suggesting that in the dog, elimination of digoxin from CSF is very rapid and that concentrations of the drug in CSF would soon be undetectable by radioimmunoassay after administration of conventional doses of the drug.

Results of limited studies on the use of cardiac glycosides in neurological and psychiatric conditions have so far proved disappointing (Neblett et al., 1972; Schott and Holt, 1974; Naylor et al., 1975); although the present observations do not preclude a potential therapeutic role, the usefulness of these glycosides in such conditions must remain in doubt.
Moreover, whilst the measurement of digoxin in plasma by radioimmunoassay has proved of value in the management of patients digitalized for cardiac disorders, no value can be foreseen in the measurement, by currently available techniques, of CSF digoxin in situations where digitilization for neuropsychiatric disorders is thought to be beneficial.

\section{Acknowledgments}

It is a pleasure to acknowledge the help and advice of Professor John Marshall and Dr Roy Goulding in the preparation of this paper, and we are grateful to the Consultants of the National Hospitals for Nervous Diseases, London, who allowed us to study patients under their care.

\section{References}

Bertler, A., Andersson, K.E. \& Wettrell, G. (1973) Concentration of digoxin in choroid plexus. Lancet, ii, 1453.

Davson, H. (1967) Physiology of the Cerebrospinal Fluid, p. 137. Churchill, London.

Doherty, J.E., Perkins, W.H. \& Flanigan, W.J. (1967) The distribution and concentration of tritiated digoxin in human tissues. Annals of Internal Medicine, 66, 116.

Editorial (1975) Problems with digoxin. British Medical Journal, 1, 49.

Garan, H., Smith, T.W. \& Powell, W.J., JR (1974) The central nervous system as a site of action for the coronary vasoconstrictor effect of digoxin. Journal of Clinical Investigation, 54, 1365.

Gillis, R.A., Pearle, D.L. \& Levitt, B. (1975) Digitalis: a neuroexcitatory drug. Circulation, 52, 739.

HolT, D.W. \& BensteaD, J.G. (1975) Postmortem assay of digoxin by radioimmunoassay. Journal of Clinical Pathol ogy, 28, 483.

Naylor, G.J., Worrall, V.P., Watson, Y., Dick, P. Stewart, M. \& PeEt, M. (1975) Trial of digoxin in mania. Lancet, ii, 639.

Neblett, C.R., McNeel, D.P., Waltz, T.A. JR \& Harrison, G.M. (1972) Effect of cardiac glycosides on human cerebrospinal-fiuid production. Lancet, ii, 1008.

SchotT, G.D. \& HolT, D.W. (1974) Digoxin in benign intracranial hypertension, Lancet, i, 358. 